\title{
From the COVID-19 pandemic to corrupt practices: a tale of two evils
}

\author{
Muhammad Usman $^{1} \cdot$ Mudassir Husnain ${ }^{1} \cdot$ Muhammad Waheed Akhtar ${ }^{2} \cdot$ Yameen Ali $^{1} \cdot$ Areej Riaz $^{1} \cdot$ Aimon Riaz $^{1}$
}

Received: 22 July 2021 / Accepted: 3 January 2022 / Published online: 8 January 2022

(C) The Author(s), under exclusive licence to Springer-Verlag GmbH Germany, part of Springer Nature 2022

\begin{abstract}
Emergencies and corruption go hand in hand in times of crisis. We are currently living in a pandemic phase, and corruption is even more damaging during these times of crisis that the world is experiencing with COVID-19. Vaccination is the only survival option that we have. The development of a nation will soon be measured by the criteria of who owns more vaccines. This study has four objectives. The first is to explore the most recent relevant literature. Moreover, we also investigate the unique trilogy of corruption, the environment, and the COVID-19 pandemic. The second is to identify adequate channels for distributing the COVID-19 vaccines. The vaccines should be dispersed based on the categories of age, gender, ethnicity, profession, and health conditions. Third, we explored the factors that are causing corruption in the distribution of the COVID19 vaccines. Our findings show that unequal distribution, theft and black markets, weaponization of vaccines, logistical challenges, and substandard and falsified vaccines are the factors that potentially lead to corruption. The fourth objective is to investigate solutions for mitigating corruption. We revealed that blockchain, awareness, well-planned distribution channels, and prioritization of vulnerable groups are the steps that could effectively reduce corruption.
\end{abstract}

Keywords COVID- $19 \cdot$ Corruption $\cdot$ Environment $\cdot$ COVID-19 Vaccination

\section{Introduction}

Today, the most significant issue throughout the world is the current pandemic, i.e., COVID-19. The World Health Organization (WHO) declared the outbreak of a novel coronavirus "a pandemic" on 11 March 2020. It is caused by the SARS-CoV-2 novel coronavirus, which has rapidly spread worldwide, creating an unprecedented public health crisis that is affecting both developed and developing countries (Ferguson et al., 2020). The whole world is striving to eliminate the virus, and many countries are even struggling to create a vaccine to fight against this virus.

Unfortunately, even during the current situation, we are still facing corruption and environmental challenges (Nicola et al., 2020; Vrushi and Kukutschka, 2021). There

Responsible Editor: Lotfi Aleya.

Muhammad Usman

1 Department of Economics and Business Administration, Division of Management and Administrative Sciences, University of Education Lahore, Lahore, Pakistan

2 Department of Management Sciences, COMSATS University Islamabad, Sahiwal, Pakistan are millions or billions of people that need the vaccine to survive, while others are attempting to generate money from this emergency. Although the COVID-19 pandemic has had a favorable impact on climate change due to lower transportation and less demand for electricity (Usman et al., 2021), the COVID-19 vaccine has opened a window for corruption, fraud, and self-dealing that can be explained by the underlying political-economic incentives at work (Rose-Ackerman, 2021).

Corruption not only involves legal wrongdoing; it also involves moral wrongdoing. Some actions may be legal in many regions but are ethically wrong or immoral, such as doing favors for people you may know by suppressing other people's rights or not doing your job correctly. In an emergency situation where a hefty amount of money has been into the economy to ease the crisis, the risk of corruption should not be underestimated (Asenova et al., 2016). To solve the problem of the current pandemic, solidarity and helping each other are needed. Nevertheless, in spite of these situations, individuals, institutions, and even states continue to behave in either malicious or unattentive ways.

Some middle-income countries did not respond well to the outbreak, such as Indonesia (Mietzner, 2020). Other nations, such as Malaysia and Vietnam, for instance, were 
widely praised for their reactions; Vietnam was especially praised because it is one of the region's poorest nations (Fleming, 2020). However, in Bangladesh, a significant section of local-level political leaders and activists are reportedly involved in widespread corruption of various types, including embezzlement, hoarding, and misappropriation of relief goods (Jonathan, 2020).

Other than unattentiveness and moral corruption, the most treacherous forms of corruption are informal payments or bribes, theft and embezzlement, favoritism, and data manipulation. The corruption of the vaccine is not too much of a concern because of some problems (ultracold storage problem); however, once vaccines are available that does not need ultracold storage and become available to local pharmacies and physicians, attempts to illegally acquire the vaccine will start. "Anything that is seen as lifesaving, lifepreserving, and that is in short supply creates black markets," said bioethicist Arthur Caplan of New York University (Goldhill and Fleur, 2020).

We are dangerously close to a time where the war will no longer be about the economic development of nations but about vaccinated and nonvaccinated countries. The fight is no longer about the wealth of the nation; it is now about who owns more vaccines. As United Nations Office on Drugs and Crime (UNODC) stated and António Guterres stressed, "Corruption is even more damaging in times of crisis the world is experiencing now with the COVID-19 pandemic" (UNODC, 2021a). Against this background, the purpose of this research is to analyze and determine the possible solutions for mitigating this problem by evaluating the difference between corrupt practices and means in developing and developed countries. More precisely, the current study intends to gauge the risk of corruption in the manufacturing and distribution of the COVID-19 vaccine. The present study is significant and may help decrease the risk of introducing a falsified vaccine into the market by making people aware of monopolistic and corrupt actions.

Prior writings have examined various sectors, including health care, as it is one of the most sensitive sectors in which the risk of corruption could substantially impact human lives (Naher et al., 2020). Corruption has drastic effects on the accessibility, quality, equal distribution, and effectiveness of health-related assistance (Lewis, 2006). Every year, billions of dollars are lost to corruption in the health care sector. Moreover, corruption is also considered a significant hurdle in achieving universal health coverage. Under these conditions, the health care sector is extremely vulnerable to corruption due to its huge amounts of funds, excessive resources, asymmetric information, multiple actors, complex systems, and global supply chain. In short, understanding the role of corruption in the health care sector is a critical factor.

Particularly in the wake of the recent pandemic, corruption has profoundly impacted the accessibility, equal distribution, quality, and effectiveness of the COVID-19 vaccine. In terms of accessibility, it is difficult for people living in developing and underdeveloped countries to access COVID-19 vaccines. Therefore, due to the lack of accessibility, people use nepotism or bribes to obtain vaccines. These unequal vaccine distributions provide a suitable environment for opportunistic players to sell low-quality or even fake vaccines in the market. Last, all of the aforementioned issues subsequently impact the effective distribution of COVID19 vaccines. These arguments reflect that these situations motivate us to explore the nexus between corruption and COVID-19 and how such an association is detrimental because it hinders the wellbeing of humanity.

This study uncovers corrupt practices in the health care sector with a particular focus on the COVID-19 pandemic. The innovation and contribution of this study toward achieving its objectives are relevant for at least four reasons. First and foremost, we review and compare the available literature in the extant literature. Second, we present the unique trilogy of corruption, the environment, and COVID-19. Third, recognizing such a potential area of inquiry, our paper illustrates the nexus between corruption and COVID-19 through recent statistical data collected from Transparency International, Global Risk Profile, and World-o-Meter. Last, the present study enriches the current knowledge by identifying the factors causing corruption in the distribution of COVID19 vaccines and provides solutions for mitigation.

The rest of the paper is organized as follows: "Literature review" section discusses the distribution of the CIVID-19 vaccine. "Corruption-Environment-COVID-19" section reveals who to should receive the vaccine first. "Methodology and statistics" section examines the factors that cause corruption in the distribution of the COVID-19 vaccine. "Distribution of COVID-19 vaccine" section presents solutions for mitigating corruption. Finally, "Factors that cause corruption in the distribution of COVID-19 vaccines" section concludes the study by providing some policy implications and future research directions.

\section{Literature review}

COVID-19 has provided a new avenue for corruption in the health care sectors around the globe. In a theoretical study, Teremetskyi et al. (2020) pointed out the recent challenges in the health division, which require inspection and devotion. These challenges are based on corrupt practices such as misuse of resources, deception in public agreements, mismanagement of funds, embezzlement of medical-related equipment, and so on. Compared to the other South Asian states, Indonesia has been performing very weakly in regard to its response to COVID-19. Consistent with the work of Mietzner (2020), who persuasively argued for the drastic influence of various factors, there are multiple reasons for 
such delayed responsiveness. Based on the research, the author found that religious dogmatism, political uncertainty, and corruption are among the prominent elements that reduced Indonesia's ability to effectively deal with major external shocks (i.e., COVID-19).

In a qualitative study on interventions as experiments, Woodside (2020) presented useful principles and tools to mitigate catastrophes varying from epidemics to social issues. The study argued that the pandemic (COVID-19), environmental challenges, corruption, human rights violations, income inequality, etc. have negative social implications that subsequently foster an intervention approach. In a cross-country analysis, Yamen (2020) studied the relationship between tax avoidance and public health exposure due to COVID-19. The sample of 138 countries was divided based on the level of corruption (i.e., high corruption and low corruption) using the corruption perception index. Their findings demonstrate a positive relationship between tax avoidance and public health exposure due to COVID19. Interestingly, the nexus between corruption and public health exposure due to COVID-19 is also positive.

Recently, a plethora of studies, i.e., an American-based study on the safety measures of COVID-19 (e.g., shelter in place or stay at home) by Dincer and Gillanders (2021), examined the linkages between corruption and adherence to social distancing. Prior studies documented that corruption can impact the level of trust, which subsequently shapes human behavior. To investigate this idea, empirical data were collected from 50 states, and the results verified that individuals who are living in highly corrupt states follow fewer of the COVID-19 restrictions.

Although the approval of different COVID-19 vaccines provides some relief to the human race, such approvals still require many restrictions. These restrictions could enhance chances for corrupt behavior to occur. In this regard, Goel et al. (2021) explored the challenges of speeding up the vaccine delivery process and found that delivering the vaccines ahead of time and the storing vaccines with unauthorized agents could potentially create incentives for corruption. The editorial report of Lancet (2021) revealed that Latin American and Caribbean countries have been greatly affected by COVID-19 (i.e., approximately $25 \%$ of global contagions and 1.3 million deaths). However, recent health care disruptions, unstable economic conditions, political unrest, inequalities, and corruption have also stimulated the pandemic.

There is a need to develop technical skills, monetary funds, and numerous strategies to enhance the procurement and distribution of COVID-19 vaccines, particularly in developing countries. Based on such a narrative, recent studies shed light on the causes that can substantially affect the disbursement of COVID-19 vaccines, for example, Chukwu and Nnogo (2021) found that vaccine fund sources, priority vaccination, handling and storage of vaccines, and corruption can substantially affect the disbursement of COVID-19 vaccines in Nigeria. Olamide and Maredza (2021) explored the causal relationship between external debt and GDP by considering the role of corruption before the outbreak of the COVID-19 scenario in South Africa. The authors used time series analysis techniques on data from 1990 to 2019. The findings of the study revealed the negative impact of corruption on the economic situation and further deteriorated growth. However, in the wake of COVID-19, such results could be different because of uncertain environments and corrupt practices.

South American countries have witnessed a quarter of total COVID-19 casualties, even though they represent only $5 \%$ of the global population. The situation in these countries has been worse because of insufficient funding to the health sector, social disparities, high poverty, slow rate of vaccination, greater spreading of new variants, and so on. Moreover, according to the study of Malta et al. (2021), this situation is expected to worsen further, and the key reasons for such acceleration are political instability, lack of health facilities, and corruption.

By considering environmental challenges, Das et al. (2020a) drew a mathematical model for green transportation that could help to reduce global warming and severe climate incidents. Moreover, Das et al. (2020b) evaluated one of the key issues prevailing in the area of location and transportation. Particularly, the authors investigated the optimum level for facilities and transportation between existing locations and the locations that are the main problems in supply chain management. The study also determined the significantly effective settings of both facility and transportation expenses through conveyances from bases to facility locations concurrently by resolving the aforementioned concern (i.e., solid transportation-p-facility location problem). Similarly, Das et al. (2021) explained an interesting model by incorporating multiple environmental concerns, e.g., facility sites, solid conveyance, and managing inventories. The study provides important insight by formulating a cohesive system for supply chain management and placement choices with the aim of reducing shipment time and overall costs, i.e., (transportation, inventory, and carbon emissions).

Apart from the environmental consequences, transportation/logistics play an important role in difficult situations, e.g., COVID-19. By considering such a narrative, Mondal and Roy (2021a) presented unique empirical models to resolve the complicated problems raised during the selection of suppliers and the allocation of orders by reducing risks and conflicts. Likewise, Mondal and Roy (2021b) proposed an open-closed loop supply chain management system, particularly for the purpose of sustainable production and delivery to hospitals during the COVID-19 pandemic.

An overview of the related previous research articles published in 2020 and 2021 is shown in Table 1. By analyzing 


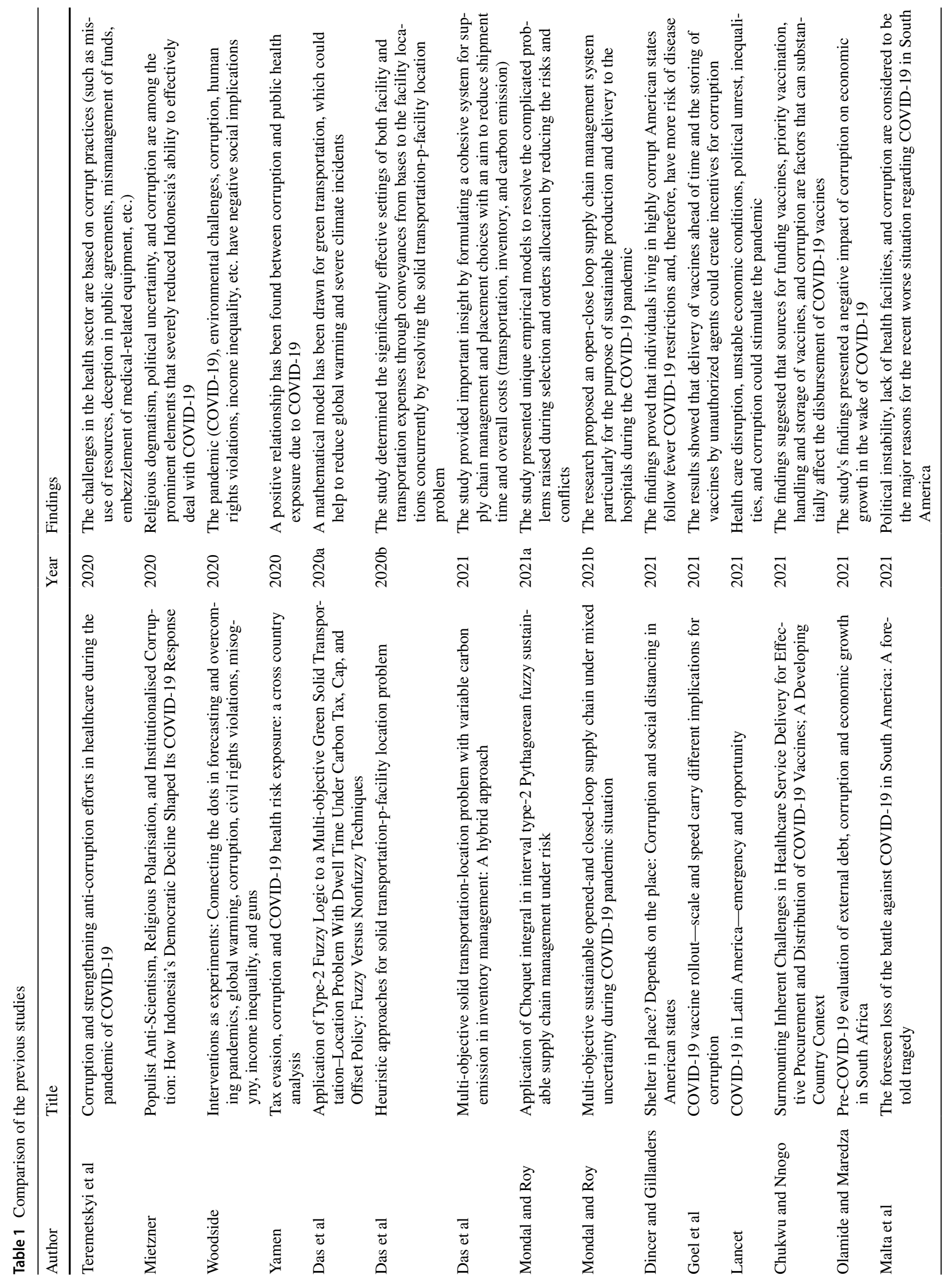


the table and the prevailing literature, a few gaps in the earlier studies can be identified as follows:

- Most of the articles only discussed either one or a maximum of two the aspects of corruption, the environment, and the COVID-19 pandemic. For example, Malta et al. (2021) discussed the COVID-19 pandemic; Olamide and Maredza (2021) and Goel et al. (2021) discussed corruption and the COVID-19 pandemic; Chukwu and Nnogo (2021) and Teremetskyi et al. (2020) discussed the COVID-19 pandemic and health care services, etc.

- To the best of our knowledge, to date, none of the studies have presented the unique cycle of corruption, the environment, and the COVID-19 pandemic. Moreover, from the thorough evaluation of the literature, we found a lack of descriptions of the effective channel to distribute/route COVID-19 vaccines.

- Last, from a diagnostic point of view, no study has identified the reasons that trigger corruption/bribery in the distribution process of COVID-19 vaccines and solutions for mitigating this issue.

To fill in the gaps observed in the prior literature completely, this study provides the following novel aspects:

- First, the present study reveals the occurrence of corruption/bribes in the health sector, particularly during the COVID-19 pandemic, and its role in creating environmental challenges. Moreover, this study presents the most recent updated review of the available literature on the topic.

- Second, this paper draws the unprecedented triangle of corruption, environment, and COVID-19 pandemic. To provide statistical support, we presented recent data collected from Transparency International, Global Risk Profile, and World-o-Meter.

- Finally, this study not only specifies an effective way to distribute COVID-19 vaccines but also detects the factors that can cause corruption in the distribution of COVID19 vaccines. Furthermore, in this study, we also document possible solutions to mitigate corruption.

\section{Corruption-Environment-COVID-19}

Corruption is a common phenomenon in both developed and developing economies. As per the OECD survey, corruption seems to have a deep impact on the environment $\left(\mathrm{CO}_{2}\right.$ emissions) in developing economies compared to developed economies (Habib et al., 2020). Generally, corruption is only linked with social and economic activities. However, an important strand of literature argues that environmental challenges are also deeply intertwined with corruption (Lopez et al., 2021; Welsch, 2004). Corruption through deprived governance, bad policies, mismanagement, and lack of enforcement eventually harms the environment (Damania et al., 2003).

At large, corruption is a severe threat to the environment, particularly because forestry, rare species, water, and fisheries are at risk. From grand corruption (licenses/permits to exploit natural resources) to petty corruption (misuse of environment-related programs), corruption is deeply rooted anywhere and everywhere (Leitão, 2016). Corruption creates possibilities to ignore or even bypass environmental laws and societal precautions. The results of this ignorance/bypass also have a repercussive effect on the lives of natives whose survival is allied to the environment (Ganda, 2020). In short, the relationship between corruption and the environment creates a significant challenge for sustainable economic growth (Wang et al., 2018; Zhang et al., 2016). Therefore, it can also be assumed that corruption impairs the environment and cruelly affects the well-being of individuals and societies (Davidson, 2021).

Environmental disruptions (e.g., climate change, pollution, biodiversity, urbanization, etc.) can severely damage human health. The most recent threat to the human race is the COVID-19 outbreak, in which the infection rate and causalities are increasing drastically (Barouki et al., 2021). However, the beginning of COVID-19 was not unanticipated because of the existing knowledge about globalization, trade, and the risk of transmission of viruses (Gibb et al., 2020). Earlier epidemics, such as SARS, MERS, and Ebola., were contained through human actions (Barouki et al., 2021). Some studies also suggested that climate change is one of the key elements of said epidemics (Bartlow et al., 2019; Ryan et al., 2019).

In light of the aforementioned literature, it is evident that different climate situations and air quality enable viruses to transmit easily (O'Reilly et al., 2020; Woodby et al., 2020). Moreover, packed residences, poor ventilation facilities, and mass transportation may also facilitate the spreading of viruses. The intensity/severity of COVID-19 is firmly connected with age and pre-existing health conditions (e.g., unhealthy lungs, heart, overweight, metabolic issues) (Guan et al., 2020). These medical issues are primarily caused by environmental factors (i.e., populated urban areas, toxic food, air pollution, and forest degradation) (Landrigan et al., 2018).

\section{Methodology and statistics}

This research is theoretical in nature. We use published research articles and reports to reach our conclusions. There are multiple reasons to choose theoretical analysis for this study. First, the focus of this study revolves around COVID-19, which is a recent health epidemic around the globe. Therefore, the empirical data are either unavailable or 
Table 2 Regional level corruption

\begin{tabular}{lcll}
\hline Region & $\mathrm{CPI}^{\mathrm{a}}$ & Region & $\mathrm{GCI}^{\mathrm{b}}$ \\
\hline Africa and Middle East & 43.37 & Africa & 58.39 \\
Asia Pacific & 45.29 & Asia & 51.48 \\
Europe and Central Asia & 35.95 & Europe & 30.33 \\
Middle East and North America & 39.11 & North America & 42.96 \\
Sub Saharan Africa & 32.31 & Oceania & 41.61 \\
Europe Union & 65.81 & South America & 46.62 \\
\hline
\end{tabular}

${ }^{\mathrm{a}} \mathrm{CPI}$-Corruption Perception Index (0-Highly Corrupt to 100-Clean) ${ }^{\mathrm{b}} \mathrm{GCI}$-Global Corruption Index (0-Low Risk to 100-High Risk)

Table 3 Regional level COVID-19 trends

\begin{tabular}{llll}
\hline Region & Total cases & Total recovered & Total deaths \\
\hline Europe & $57,078,033$ & $52,243,456$ & $1,196,281$ \\
North America & $50,784,405$ & $39,320,493$ & $1,034,057$ \\
Asia & $73,234,533$ & $69,010,166$ & $1,084,442$ \\
South America & $37,287,587$ & $35,389,651$ & $1,142,645$ \\
Africa & $8,155,408$ & $7,395,894$ & 204,501 \\
Oceania & 192,353 & 126,880 & 2,479 \\
\hline
\end{tabular}

Source: World-o-Meter.

statistically unreliable. Second, we are currently in the phase of an ongoing pandemic. Thus, it is quite difficult to measure the total cost of corruption. Last, corruption, in general, particularly in the health sector, is mainly underreported or in some cases not reported at all, so the true impact of corruption is difficult to uncover.

We use statistical data to support the theoretical grounds regarding corruption and COVID-19. We collect data from multiple sources, i.e., Transparency International, Global Risk Profile, and World-o-Meter. These sources are reliable for evaluating the level of corruption and recent COVID19 statistics. Particularly, Table 2 shows the regional-level corruption records. Furthermore, Table 3 presents regionallevel COVID-19 trends concerning total cases, total recoveries, and total deaths.

\section{Distribution of COVID-19 vaccine}

\section{Access to vaccine}

Access to the COVID-19 vaccine is an essential concern for both developing countries and the countries that are most affected by COVID-19 because developing countries are primarily corruption-affected nations, and the countries affected by COVID-19 are where people are fighting to survive the virus (Steingrüber et al., 2020).

\section{Developing countries}

When the central issue of corruption needs to be addressed, developing countries cannot be overlooked. Developing countries are the most vulnerable to corruption because they are composed of shadow economies, deficient health care, and poor education systems (Elvin, 2020). Moreover, developing countries mostly have unstable economies and therefore cannot fulfil the conditions needed for the amelioration of people. People living in developing countries likely have minimum or very little access to health care services compared to people living in developed countries (Peters et al., 2008). Similarly, there are multiple health care issues in developing countries raised due to sociocultural, economic, and political factors (Chudi, 2010).

\section{Pandemic affected countries}

According to Worldometer, the top three countries most affected by COVID-19 are the USA, India, and Brazil, followed by France, Turkey, Russia, the UK, and Italy. It is evident that people are fighting for their lives in countries where COVID-19 is prevalent; however, many politicians are suppressing the science. In the USA, the government of President Trump exploited the Food and Drug Administration to quickly approve unproven drugs (Khan et al., 2020). However, the phenomenon of corruption in the distribution of the COVID-19 vaccine is not only US-based. Brazil is also a vulnerable country; while other nations and municipal governments have exercised social distancing along with measures to control the pandemic, Bolsonaro (the President of Brazil) has strictly opposed measures and compared COVID-19 with the flu or a cold (Ortega and Orsini, 2020). England's Department of Health delayed the publication of a report; a segment on ethnic minorities was initially retained and then, after public exclamation, was published as part of an investigative report (Khan et al., 2020). Such practices have been implemented in other affected countries as well.

\section{Route of the vaccine}

Given the scarcity of vaccines, one plausible recommendation is to correctly manage the route and availability of the vaccine supply; in doing so, authorities should announce health emergency campaigns for their provision at appropriate places and ensure that they are placed in the right hands. The most affected people would need vaccines immediately, which could help to reduce the overall mortality rate. Indeed, factors that are currently important for vaccination are age, gender, ethnicity, profession, prevalence in a community, 
and those who have already been infected by COVID-19 (Krelle and Tallack, 2020).

Thus, the critical question at this stage is who should receive the vaccine first.

\section{Healthcare workers}

Nobody is in greater danger of contracting infectious diseases or of transmitting them compared to healthcare staff. Thus, hospitals provide guidelines to their workers to receive immunization for their protection and the safety of patients, guests, family, and fellow workers (Field, 2009). COVID-19 is an infectious disease that requires the same protocols for healthcare workers. Healthcare staff can be exposed to the COVID-19 virus both at the workplace and in the community. During the time of the pandemic, there is an enormous need for healthy and uninfected medical workers to handle patients properly. The government should prioritize vaccinating frontline health workers (Meskell, 2020). As frontline health workers are providing services to patients, it is imperative for them to receive the vaccination first.

\section{Patients with pre-existing health issues}

Patients with pre-existing illnesses (such as diabetes and kidney issues) need to receive priority treatment because the infection rate of COVID-19 is severe in this group of people. According to Clinic (2021), diabetic patients develop more severe COVID-19 disease. Patients with diabetes are more susceptible to the virus, as this disease weakens their immune system. India has reportedly seen black fungus (a fungal infection) in 7200 patients with COVID-19, and doctors think diabetes is to blame.

\section{Gender}

Most scientists call COVID-19 a gender-biased virus. However, the immune system is mostly to blame for this. In males, the proteins that defend the body against infection and viruses do not work the same way (Gerrard and Barton Cunningham, 2003). In regard to immunizations, females are considered superhuman (Lawry, 2021). Women have greater immunity than men because men are more exposed to the external environment and, therefore, are considered more vulnerable to diseases. According to research, men are $20 \%$ more likely to be hospitalized than women when infected or exposed to the disease (Klein and Flanagan, 2016). It has also been found that the mortality rate from COVID-19 among males is higher than that among females for all age groups (Contreras et al., 2021).
Age

Older adults are most exposed to viruses and infections as their immune systems become weak with age. According to Baack et al. (2021), people in their $50 \mathrm{~s}$ are higher at risk for severe illness than people in their $40 \mathrm{~s}$. Likewise, people in their $60 \mathrm{~s}$ or $70 \mathrm{~s}$ are more at risk for severe illness than people in their $50 \mathrm{~s}$. The highest risk of fatal illness due to COVID-19 is among those 85 years of age or older.

\section{Ethnicity}

According to the study published by Smith (2021), COVID19 has unequally affected many racial and ethnic minority groups, putting them at risk of becoming ill and dying. People of the black race are four times more likely to die from COVID-19 than white Bangladeshi/Pakistani men and women (Krelle and Tallack, 2020). Some health scientists think that the racial marks of COVID-19 may be due to the poor health conditions available to them. Others are more concerned about genetic or other biological factors that make individuals prone to fatal health issues, and such higher mortality associated with COVID-19 is an important research area that needs attention (Hooper et al., 2020).

\section{Factors that cause corruption in the distribution of COVID-19 vaccines}

At the time of the crisis, there was a huge demand for emergency funds, mostly in developing countries with shadow economies and unstable economies. The swift rollout of emergency payments to individuals and firms intensifies corruption risks, such as inducement, scams, and stealing (Rose-Ackerman, 2021). The main concern for the state in the distribution of vaccines is that the vaccines are dispersed not only rightfully but also from the right hands. As Geoghegan (2020) said, COVID-19 has set free state corruption at a large scale, which is deadly to public health. The following are some of the factors that can cause corruption in the distribution of the COVID-19 vaccine.

\section{Unequal distribution}

As many pharmaceutical companies have come up with their versions of the COVID-19 vaccine, equitable distribution is now a challenge. Developed nations have bought many doses of the vaccine for their populations. As Priborkin (2021) stated, developed countries have obtained a more significant chunk of the vaccines, while developing countries desperately need doses for their masses. On the other hand, lower-income countries face many challenges, as they have to feed their people and vaccinate them while their 
low-performing economies are shrinking. The dilemma will be worse if global communities do not consider this when distributing the vaccines.

Developed countries have the infrastructure to distribute coronavirus vaccines fairly and equally, but developing countries, such as countries of South Asia, Central African countries, and other parts of the world, lack the infrastructure to facilitate the equal distribution of coronavirus vaccines. Therefore, there are more chances for unequal distribution; as Acharya et al. (2021) stated, countries should ensure that they have the needed infrastructure for broad vaccination campaigns.

Those lacking infrastructure, the overall vaccine perception, should work on both sides as these are somehow equally important as for as the immunization of old to young populations is concerned. Lower-income countries also have fewer literate people in their overall population, which is a risk in the immunization process, as uneducated people are not aware of the vaccines and consequently, they are left untapped, causing hurdles in the vaccination process (Burki, 2021). Another critical factor is geographical location; for example, the northern areas of Pakistan are mountainous, some parts of south Punjab and north Sindh have unpopulated areas and many remote areas all around the country, where the instability, unavailability of infrastructure, and other issues, such as security, are important considerations to understand when designing a campaign to vaccinate. Similarly, countries such as India, Nepal, Bhutan, and Bangladesh in South Asia and MENA (the Middle East and North Africa) countries have the same types of issues. Some other countries of the world also face similar problems in the equal distribution of vaccines, which is essential to save people from COVID-19 (ANI, 2021).

Developed countries with high purchasing power and sufficient money to feed their population are blamed for the unequal COVID-19 vaccine distribution. Some have been perceived as creating a hegemony or monopoly on the manufacturing and distribution of the vaccine, as the USA imposed a ban on the export of AstraZeneca and the necessary raw material needed to create vaccines (Legge and Kim, 2021). Similar types of restrictions have been reported about the UK but government officials denied such actions. Some companies have even formed alliances, such as German BioNTech with Pfizer; the critics said these are for financial gains, as these pharmaceutical companies said they might need a year to validate vaccine manufacturing sites (BBC, 2021). These factors can subsequently open the window for corrupt practices.

\section{Theft and black market}

Transparency would be a top priority if it is neglected and will have negative impacts on the distribution of the vaccine. The other risk is theft; if manufacturing is left unchecked, false vaccines will enter the market; some administrative personnel can steal the vaccine inventory and sell it in the black market (UNODC, 2021b). Negative word of mouth and a perception of being neglected or deprived may prevail in the world's major population (Rahman, 2021).

Opaque contracts that keep the price a secret can hide corruption, such as bribes, personal interest, and commission. However, in this situation, corruption mainly occurs when the officials of low-income countries purchase vaccines from pharmaceutical companies (Transparency-International, 2021). When the agreement between the two parties (governments and pharmaceutical companies) is kept secret/confidential, the probability of corruption is enhanced (UNODC, 2021b). Bribery is another huge challenge because greedy public servants in low-income countries may demand bribes to provide vaccinations, consequently discouraging people from receiving vaccinations.

\section{Weaponizing the vaccine}

The limited supply of the COVID-19 vaccine with high demand from desperate populations could lead to theft and diversion. If many people are left without the vaccine, the inequality between developing and developed countries may create conflict between different world countries (Transparency-International, 2021). Most countries lack the infrastructure to handle this emergency health situation. The developing world, mainly South Asia, MENA, some countries of North America, and the Caribbean countries, face great risks regarding health services (Rahman, 2021), distribution and logistical support, and government regulations (Jonathan, 2020).

Many countries have developed vaccines, e.g., Sputnik V, Moderna, Sinopharm, AstraZeneca, and Pfizer-BioNTech (UNODC, 2021b). However, the acceptance of these vaccines varies country-to-country. Some called Russia a nationalistic country, as they introduced its vaccine into the market early, so most European countries did not recognize and accept the Russian and Chinese versions of the COVID-19 vaccine. The world divide began at the start of this pandemic, and the blame game has turned into a divide and now traveling restrictions, control movement of goods and services to the world from the COVID-19 vaccination perspective and this division is not between the vaccinated and nonvaccinated world, but is a divide caused by pharmaceutical companies based on the quality and the efficacy of the different vaccines (Jonathan, 2020). Thus, to get the vaccines approved and accepted, pharmaceutical companies offered formal and informal payments to corrupt health care officials. 


\section{Logistical challenges}

Logistics involves the business of moving goods from one place to another, mainly to end users. The novel coronavirus sets new and difficult challenges for logistical firms across the world. Contrary to the conventional modes, some great gains during the whole episode, from manufacturing to distribution have been experienced; here comes the logistics to enter into the field. Vaccine availability throughout the world is impossible without robust logistical support because the distribution depends significantly on adequate transportation (Margi et al., 2021).

In regard to the distribution of the COVID-19 vaccine, the fundamental essentials include cold chain, storage capacity, and end deliveries. Most vaccines need temperature support, e.g., Pfizer-BioNTech should be stored under $-70{ }^{\circ} \mathrm{C}$, which is a tough task for the supply chain or logistical support that we have today (SEKO, 2021). The typical cold supply is approximately $4{ }^{\circ} \mathrm{C}$ when they transport specific medical supplies. Similarly, Moderna could sustain temperatures ranging from 2 to $8^{\circ}$ for a month (Clarence, 2021). Storage capacity is a complex task for developing countries, where a shortage of energy causes power cuts that might make refrigerators stop working and make vaccine doses useless (Margi et al., 2021). Storage requirements are a challenging task for South America, Asia, and Africa, as they have hot climates, and it is very complicated to manage the supplies.

Considering all the aforementioned concerns, it would be difficult to supply the COVID-19 vaccine to remote areas (SEKO, 2021). For delivery to remote areas or farflung destinations, a specialized medical force is needed. The pharmacies would be responsible for the distribution of the vaccine. Therefore, opportunistic individuals/officials involved in corrupt practices may obtain easy access to the vaccine.

\section{Substandard and falsified vaccines}

Early approvals and the introduction of any vaccine will be more harmful than curing or controlling the pandemic. Compromising transparency in all the steps in the process of manufacturing, allocation, and distribution of vaccines promotes skepticism to prevail and undermines the importance of being vaccinated (UNODC, 2021b). Substandard and falsified vaccines will be inducted into the market as a consequence, which would risk the lives of millions of people (Transparency-International, 2021). Vaccination is essential, but it should be safe and reliable enough to make the life of the infected and noninfected population immune to this novel pandemic (Rahman, 2021). These early approvals of vaccines could have been obtained through bribery.

\section{Corruption mitigating solutions}

Corruption is predominantly destructive, threatening economic development, international security, and public health. Concurrently, the nature of corruption in the health sector is adaptable and complex, making it tremendously complicated to overcome, regardless of the enormous costs of billions of dollars (Fazilov, 2021). The following are the few actions that can substantially mitigate the risk of corruption in the distribution of the COVID-19 vaccine.

\section{Blockchain}

Although the citizens of rich countries will receive the COVID-19 Vaccine this year, many people in developing countries will likely wait for years to obtain one. The main concern is to make it possible to distribute the vaccine among the rich and poor in an equitable way, ensuring that everyone has the right to receive the vaccine. Rich countries should prioritize their citizens but developing countries should also receive vaccines. COVID-19 is all about how interconnected we all are globally and how a virus crosses borders without regard to nationality, ethnicity, class, race, or gender (Wendy R, 2021).

COVID-19 vaccine global access, generally known as COVAX, is a worldwide act and worldwide initiative to provide equitable access to vaccines. Several different ways have been introduced for the fair distribution of vaccines. COVAX collaborates to bring together government, companies, international organizations, and others to speed up the development and manufacture of COVID-19 vaccines (Nicole, 2021). Dr. Tedros has criticized wealthier nations for hoarding COVAX and has accused them of hoarding the global vaccine supply by ordering multiples times more than the actual needs of their populations (BBC, 2021).

COVAX currently aims to provide $0.3 \%$ vaccination to developing countries and 50\% vaccination to rich countries. Another "Fair Priority" proposal suggests that once the COVID-19 transmission rate drops below a certain level in the countries with the vaccine, it will contribute to global distribution (Binghamton University,2021). Berlinbased NGO wrote in its annual (CPI) Corruption Perception Index "The Coronavirus crisis isn't just a crisis of health and economy, but a crisis of corruption as well, with the lives of countless lost as a result of corruption" (Jules, 2021). Therefore, to prevent corruption, fraud, and wastage, member states should establish clear and transparent criteria to ensure that those in greatest need of assistance qualify for and receive it. To address corruption and prevent it from happening, institutions must create a quick response, such as an emergency plan, to address corruption in the distribution of vaccines in its very first stage. 


\section{Awareness}

Currently, where the coronavirus is at its peak, people are ready to give every asset they have to purchase their health in the form of COVID-19 vaccines without knowing whether the source is right or not or without knowing the threat of the falsified vaccines entering the market. COVAX signed up to distribute enough vaccines to protect at least $20 \%$ of the population of the poorer countries. According to experts, even if the target is achieved, it falls short of the level of immunity needed to end the pandemic (BBC, 2021). Stopping the pandemic will require at least $70 \%$ of the global population to have immunity, as suggested by the WHO.

Where the pandemic is at its peak, the demand for the vaccine is unmet because the supply is always falling short of the total numbers of vaccines needed to treat the patients. With urgent global demand for the vaccine, there is a risk of falsified and substandard vaccines entering the market. The use of a falsified vaccine can not only make people afraid to get properly tested, it can also cause people to lose their trust in vaccination and the institution providing them even though they are trying to protect the people from disease. Esteve said, "It's important to stress that any danger caused by fake vaccines doesn't reflect any safety failure of an authentic it genuine version" (DW, 2021).

The government cannot reach every single vaccination center, ensure fair distribution and administer the vaccine. Nevertheless, the government can at least punish those who are involved in corrupt practices and make them an example for others, said Amir Aqil (DAWN, 2021). As the vaccine entered the market, it opened the route to corruption. Transparency, accountability, integrity, and multistakeholder participation must contribute to COVID-19-related programs, plans, and policies (Transparency-International, 2021). Favoritism, nepotism, conflict of interest, corrupted procurement services, and undue influence of companies are the few areas that need to be addressed. The public must be aware of these practices to reduce the risk of corruption practices (Rahman, 2021).

\section{Well planned distribution channels}

The distribution channels must be administered and monitored correctly and regularly by the government. The authorities must fully focus on the distribution of the vaccination to deliver it to the people and institutions through the right hands and to reduce the risk of corruption during this distribution by addressing the corruption in its early stage and by apprehending those who are involved in corrupt practices and making them an example for others to abide by rules and regulations.

The distribution of vaccines can be categorized into the following three main components (i.e., from the factory to the frontlines): first, through partnership with state, local and tribal health department territories, federal entities, and tribes to allocate and distribute vaccines, augmented by direct distribution to commercial partners; second, a centralized distribution contract with potential backup distributors for additional storage and handling requirements; last, a flexible, scalable, secure web-based I.T. vaccine tracking system for ongoing vaccine allocation, ordering, uptake, and management.

The global supply chain has slowed down during the pandemic, and product delays and labor shortages have complicated the matter even more. Planning for the additional raw material and supplies that will be needed to distribute the vaccine is also a difficult task to accomplish. The demand for the Vaccine remains unmet, which opens the door for corruption and gives a new way for corrupt hands to hoard funds. Vials, rubbers, syringes, stoppers, and plungers will need to be available in quantities of hundreds of millions, and the distribution issue, shortage, and confusion of medical supplies currently being experienced to fight the virus should be a warning of much-needed planning for the near future (Kim, 2020).

\section{Prioritization of vulnerable groups}

The short supply and the unmet demand for the Vaccine have made governments and public health institutions take a step to prioritize certain groups, so they can protect the lives of vulnerable groups of society. The CDC recommended vaccine prioritization to decrease the death rate, preserve society's functioning, and address disparities (Mark, 2021).

Prioritization has benefits because people differ in at least two ways: their risk of infection and their likelihood of severe consequences from infection. ACIP (Advisory Committee on Immunization Practices) recommends a schedule for the distribution of vaccination, including nonhealthcare frontline essential workers and people aged more than 75 years in phase $1 \mathrm{~b}$ and people aged 65 to 74 and those aged 16 to 64 with high-risk medical conditions in phase 1c2. Recently, the CDC also recommended considering ethnic minorities within phase $1 \mathrm{~b} 4$, which is within the parameters of essential worker vaccination.

\section{Conclusion}

COVID-19 has taken a toll on the lives of thousands. The condition has become increasingly severe for every new wave of COVID-19. Every new wave presents a new variant in the pandemic, making it increasingly severe and dangerous. SARS-COV-2 was rapidly sequenced by Chinese researchers as an RNA molecule with 30,000 bases containing 15 genes, including the $\mathrm{S}$ gene, which encodes a protein 
located on the surface of the viral envelope (Alexandre, 2020). Currently, vaccination is considered the only way to eliminate the virus. Many countries are trying their best to develop a vaccine to fight against this virus.

The rich will try to acquire or store more vaccines, and it will be difficult for poor/middle-class people to obtain the vaccine. This research will discuss ways to distribute the vaccine and ensure fair distribution equally. Taking into view estimations of "Transparency International," approximately 140,000 children die per year because of corruption in health systems (Farzanegan, 2021). The rush of the demand for vaccines will cause people to pay any price for it, but the main concern is that people do not know whether they are getting a suitable vaccine or not. When the distribution of vaccines starts, people will try to take a vaccine from any available source, not knowing if it is the right one.

For the community, little is known about the safety of vaccines. There is little to no knowledge about the preparation of vaccines and their unmet demand; people are willing to pay for immunity without even knowing if they are getting a suitable vaccine or not, which will open the doors to corruption. Therefore, this is one of the major concerns of our research area other than the fair distribution of vaccines. This research will warn people to take vaccines from the right resources because a fabricated vaccine can threaten the lives of humans and is a serious health hazard.

The current pandemic has highlighted that items in high demand with a short supply, such as vaccines, personal protective equipment, swabs, ventilators, and potential therapeutic medicines, are especially vulnerable to fraud and corruption. To address corruption, it is essential to create specialized committees with a robust anti-corruption mandate to oversee the distribution, prioritization, and monitoring of vaccine-related programs. Moreover, the functions of these committees should also include the capability to monitor the emergency disbursement of the funds, the distribution of vaccines, and the purchase of vaccines. To counter reacting nepotism, favoritism, undue influence, and political bias in identifying targets and groups, planning for the vaccine distribution and identification of the vulnerable population needs to be transparent to ensure that the access is equitable and citizens understand who will receive vaccines and who will not.

Irrespective of all the aforementioned cautions, two important implications can be derived from the study. First, COVID-19 is a worldwide phenomenon and a threat to the human race, and vaccination is the only survival option we have at the moment. Second, the vaccination of COVID-19 has opened a window for corruption and fraudulent activities. Therefore, in this study, we documented the factors that cause corruption to penetrate the distribution of COVID-19 vaccines. Moreover, we also presented effective solutions to mitigate the danger of corruption. This paper provides recommendations to the government and individuals. On the individual level, the public is encouraged to get vaccinated as early as possible so that the world can be free from COVID-19. On the government front, the results suggest drawing effective policies and procedures to prevent corruption from every sector.

Apart from all the significant policy implications, this study does have some limitations as well. We only investigate corruption as a social phenomenon that can impact the COVID-19 vaccination process; however, there are some other influential factors as well, e.g., risk of postvaccination health issues, incorrect perceptions, lack of proper guidance, inappropriate behavior of individuals/societies, etc. Future researchers can incorporate these elements to enhance the existing knowledge on this topic. Currently, we are in the phase of an ongoing pandemic. Therefore, it is quite difficult to estimate the total cost of corruption. However, sooner or later, the intensity of the current pandemic will slow down so that future studies could quantify the cost of corruption and its economic implications. Overall, corruption needs to be addressed as early as possible to avoid the forming of any black market, which can further trigger the whole situation.

Acknowledgements The authors would like to thank Prof. Dr. Chunhui Huo (Dean Asia-Australia Business College, Liaoning University, P.R. China) for his insightful comments, and invaluable feedback.

Author contribution M.U. originated and intended the research, AR1 completed the literature survey on the topic, AR2 accomplished the statistical facts, Y.A. assisted in the compilation of data from diverse sources, and M.H. and MWA finalized and prepared the draft.

Funding This research received no grant.

Data availability Publicly available databases are being used in this study, e.g., World-O-Meter (https://www.worldometers.info), BBC (https://www.bbc.com/news/), Transparency International (https:// www.transparency.org), etc.

\section{Declarations}

Ethics approval and consent to participate Ethical approval is not applicable. For this study, we use publicly available data. Therefore, no permission from the participant is required.

Consent for publication No publication consent is required.

Competing interests The authors declare no competing interests.

\section{References}

Acharya KP, Ghimire TR, Subramanya SH (2021) Access to and equitable distribution of COVID-19 vaccine in low-income countries. npj Vaccines 6(1):1-3. https://doi.org/10.1038/ s41541-021-00323-6 
Alexandre, H. (2020). Coronavirus origins: genome analysis suggests two viruses may have combined. Retrieved from https:// www.google.com/amp/s/theconversation.com/amp/coronavirusorigins-genome-analysis-suggests-two-viruses-may-have-combi ned-134059

ANI. (2021). Amid looming shortfall of doses, UNICEF calls for global, equitable distribution of COVID-19 vaccines. Retrieved from https://www.aninews.in/news/world/us/amid-looming-short fall-of-doses-unicef-calls-for-global-equitable-distribution-ofcovid-19-vaccines20210518103906/

Asenova, D. D., Bancheva, S. V., \& Asenov, I. V. (2016). Emergency medical care services in Republic of Bulgaria-structure, functions and actual status of medical staff. Евразийский Союз Ученых(3-2 (24)). https://doi.org/10.31618/ESU.2413-9335

Baack, B. N., Abad, N., Yankey, D., Kahn, K. E., Razzaghi, H., Brookmeyer, K., . . . Singleton, J. A. (2021). COVID-19 vaccination coverage and intent among adults aged 18-39 years-United States, March-May 2021. https://doi.org/10.15585/mmwr.mm7025e2

Barouki R, Kogevinas M, Audouze K, Belesova K, Bergman A, Birnbaum L, Drakvik E (2021) The COVID-19 pandemic and global environmental change: emerging research needs. Environ Int 146:106272. https://doi.org/10.1016/j.envint.2020.106272

Bartlow AW, Manore C, Xu C, Kaufeld KA, Del Valle S, Ziemann A, Fair JM (2019) Forecasting zoonotic infectious disease response to climate change: mosquito vectors and a changing environment. Veterinary Sciences 6(2):40. https://doi.org/10.3390/vetsci6020 040

BBC. (2021). COVID-19: Macron calls on US to drop vaccine export bans. Retrieved from https://www.bbc.com/news/world-europe57039362

Burki T (2021) Equitable distribution of COVID-19 vaccines. Lancet Infect Dis 21(1):33-34. https://doi.org/10.1016/S1473-3099(20) 30949-X

Chudi IP (2010) Healthcare problems in developing countries. Medical Practice and Reviews 1(1):9-11. https://doi.org/10.5897/MPR. 9000011

Chukwu, O. A., \& Nnogo, C. C. (2021). Surmounting inherent challenges in healthcare service delivery for effective procurement and distribution of COVID-19 vaccines; a developing country context. Health Policy and Technology.https://doi.org/10.1016/j. hlpt.2021.100518

Clarence, H. (2021). The logistics challenges of COVID-19 vaccine distribution prove the need for data integrity. Retrieved from https://www.globaltrademag.com/the-logistics-challenges-ofcovid-19-vaccine-distribution-prove-the-need-for-data-integrity/

Clinic, M. (2021). How does COVID-19 affect people with diabetes? . Retrieved from https://www.mayoclinic.org/diseases-conditions/ coronavirus/multimedia/how-does-covid-19-affect-people-withdiabetes/vid-20510584

Contreras, L. E. V., Perkins, K. M., Ellenbecker, M., Moure-Eraso, R., \& Vega, N. E. M. (2021). COVID-19 pandemic lessons to facilitate future engagement in the global climate crisis. Journal of Cleaner Production, 125178.https://doi.org/10.1016/j.jclepro. 2020.125178

Damania R, Fredriksson PG, List JA (2003) Trade liberalization, corruption, and environmental policy formation: theory and evidence. J Environ Econ Manag 46(3):490-512. https://doi.org/10.1016/j. jclepro.2020.125178

Das, S. K., Pervin, M., Roy, S. K., \& Weber, G. W. (2021). Multiobjective solid transportation-location problem with variable carbon emission in inventory management: A hybrid approach. Annals of Operations Research, 1-27.https://doi.org/10.1007/ s10479-020-03809-Z

Das SK, Roy SK, Weber G-W (2020a) Application of type-2 fuzzy logic to a multiobjective green solid transportation-location problem with dwell time under carbon tax, cap, and offset policy: fuzzy versus nonfuzzy techniques. IEEE Trans Fuzzy Syst 28(11):2711-2725. https://doi.org/10.1109/TFUZZ.2020. 3011745

Das SK, Roy SK, Weber GW (2020b) Heuristic approaches for solid transportation-p-facility location problem. CEJOR 28(3):939961. https://doi.org/10.1007/s10100-019-00610-7

Davidson S (2021) The world wants to reopen: will vaccine passes be the key? Biometric Technology Today 2021(6):5-7. https://doi. org/10.1016/S0969-4765(21)00070-9

DAWN. (2021). Vaccine Corruption. Retrieved from https://www. google.com/amp/s/www.dawn.com/news/amp/1621955

Dincer O, Gillanders R (2021) Shelter in place? Depends on the place: corruption and social distancing in American states. Soc Sci Med 269:113569. https://doi.org/10.1016/j.socscimed.2020.113569

DW. (2021). Officials warn of fake COVID-19 vaccines. Retrieved from https://www.google.com/amp/s/amp.dw.com/en/officials-warn-offake-covid-19-vaccines/a-56123830

Elvin, M. (2020). How corruption affects emerging economies. Retrieved from https://www.investopedia.com/articles/investing/ 012215/how-corruption-affects-emerging-economies.asp

Farzanegan, M. R. (2021). The effect of public corruption on COVID19 fatality rate: a cross-country examination. https://doi.org/10. 2139/ssrn.3805464

Fazilov F (2021) Anti-corruption review in global health. Ilkogretim Online 20(3):1617-1620. https://doi.org/10.17051/ilkonline.2021. 03.182

Ferguson, N. M., Laydon, D., Nedjati-Gilani, G., Imai, N., Ainslie, K., Baguelin, M., . . Cuomo-Dannenburg, G. (2020). Impact of non-pharmaceutical interventions (NPIs) to reduce COVID-19 mortality and healthcare demand. Imperial College COVID-19 Response Team. Imperial College COVID-19 Response Team, 20. https://doi.org/10.25561/77482

Field, R. I. (2009). Mandatory vaccination of health care workers: whose rights should come first? Pharmacy and Therapeutics, 34(11), 615. Retrieved from https://www.ncbi.nlm.nih.gov/pmc/ articles/PMC2810172/?report=classic

Fleming, S. (2020). Viet Nam shows how you can contain COVID19 with limited resources. World Economic Forum, 3. Retrieved from https://www.weforum.org/agenda/2020/03/vietnam-conta in-covid-19-limited-resources/

Ganda F (2020) The influence of corruption on environmental sustainability in the developing economies of Southern Africa. Heliyon 6(7):e04387. https://doi.org/10.1016/j.heliyon.2020.e04387

Geoghegan, P. (2020). Cronyism and clientelism. London Review of Books, 42(21), 9-12. Retrieved from https://www.lrb.co.uk/thepaper/v42/n21/peter-geoghegan/cronyism-and-clientelism

Gerrard P, Barton Cunningham J (2003) The diffusion of internet banking among Singapore consumers. International Journal of Bank Marketing 21(1):16-28. https://doi.org/10.1108/0265232031 0457776

Gibb R, Redding DW, Chin KQ, Donnelly CA, Blackburn TM, Newbold T, Jones KE (2020) Zoonotic host diversity increases in human-dominated ecosystems. Nature 584(7821):398-402. https://doi.org/10.1038/s41586-020-2562-8

Goel RK, Nelson MA, Goel VY (2021) COVID-19 vaccine rolloutscale and speed carry different implications for corruption. Journal of Policy Modeling 43(3):503-520. https://doi.org/10.1016/j. jpolmod.2021.04.003

Goldhill, O., \& Fleur, N. S. (2020). There absolutely will be a black market': How the rich and privileged can skip the line for Covid19 vaccines. Retrieved from https://www.statnews.com/2020/12/ 03/how-rich-and-privileged-can-skip-the-line-for-covid19-vacci nes/

Guan, W.-j., Liang, W.-h., Zhao, Y., Liang, H.-r., Chen, Z.-s., Li, Y.-m., . . W Wang, T. (2020). Comorbidity and its impact on 1590 patients with COVID-19 in China: a nationwide analysis. 
European Respiratory Journal, 55(5). https://doi.org/10.1183/ 13993003.00547-2020

Habib S, Abdelmonen S, Khaled M (2020) The effect of corruption on the environmental quality in African countries: a panel quantile regression analysis. J Knowl Econ 11(2):788-804. https:// doi.org/10.1007/s13132-018-0571-8

Hooper MW, Nápoles AM, Pérez-Stable EJ (2020) COVID-19 and racial/ethnic disparities. JAMA 323(24):2466-2467. https://doi. org/10.1001/jama.2020.8598

Jonathan, C. (2020). Opinion: The unspoken COVID-19 vaccine challenges-distribution and corruption. Retrieved from https:// www.devex.com/news/opinion-the-unspoken-covid-19-vaccinechallenges-distribution-and-corruption-98437

Jules, D. (2021). Corruption kills during coronavirus pandemic. Retrieved from https://www.google.com/amp/s/www.politico. eu/article/corruption-kills-during-coronavirus-pandemic-report/ amp/

Khan MK, Khan MI, Rehan M (2020) The relationship between energy consumption, economic growth and carbon dioxide emissions in Pakistan. Financial Innovation 6(1):1-13. https:// doi.org/10.1186/s40854-019-0162-0

Kim, O. (2020). Preparing the supply chain for a coronavirus vaccine. Retrieved from https://www.healthcarepackaging.com/ logistics-distribution/logistics-supply-chain/article/21131384/ preparing-the-supply-chain-for-a-coronavirus-vaccin

Klein SL, Flanagan KL (2016) Sex differences in immune responses. Nat Rev Immunol 16(10):626-638. https://doi.org/10.1038/nri. 2016.90

Krelle, H., \& Tallack, C. (2020). The COVID-19 vaccine: who gets it first? The Health Foundation, UK, December. Retrieved from https://www.health.org.uk/publications/long-reads/the-covid19-vaccine-who-gets-it-first

Lancet T (2021) COVID-19 in Latin America-emergency and opportunity. Lancet (london, England) 398(10295):93. https:// doi.org/10.1016/S0140-6736(21)01551-8

Landrigan, P. J., Fuller, R., Acosta, N. J., Adeyi, O., Arnold, R., Baldé, A. B., . . Breysse, P. N. (2018). The Lancet commission on pollution and health. The lancet, 391(10119), 462-512. Retrieved from https://www.thelancet.com/commissions/pollu tion-and-health

Lawry, L. (2021). Sex, gender, and vaccines: considerations for COVID-19 vaccine immunity. Management sciences for health. Retrieved from https://ghsupplychain.org/news/sex-gender-andvaccines-considerations-covid-19-vaccine-immunity

Legge DG, Kim S (2021) Equitable access to COVID-19 vaccines: cooperation around research and production capacity is critical. Journal for Peace and Nuclear Disarmament 4(sup1):73-134. https://doi.org/10.1080/25751654.2021.1906591

Leitão, A. (2016). Corruption and the Environment. Journal of Socioeconomics, 5(3). https://doi.org/10.4172/2167-0358.1000173

Lewis, M. (2006). Governance and corruption in public health care systems. Center for Global Development working paper, (78). Retrieved from http://www1.worldbank.org/publicsector/antic orrupt/Corruption\%20WP_78.pdf

Lopez L, Hart LH, Katz MH (2021) Racial and ethnic health disparities related to COVID-19. JAMA 325(8):719-720. https://doi.org/10. 1001/jama.2020.26443

Malta, M., Vettore, M. V., da Silva, C. M. F. P., Silva, A. B., \& Strathdee, S. A. (2021). The foreseen loss of the battle against COVID19 in South America: A foretold tragedy. EClinicalMedicine, 39.https://doi.org/10.1016/j.eclinm.2021.101068

Margi, V. G., Ludwig, H., Detlev, M., \& Christoph, W. (2021). Is the world up to the challenge of mass COVID-19 vaccination, Travel, logistics and infrastructure. Retrieved from https://www.mckin sey.com/industries/travel-logistics-and-infrastructure/our-insights/ is-the-world-up-to-the-challenge-of-mass-covid-19-vaccination\#
Mark, B. (2021). Ethics at center of COVID-19 vaccine distribution debate: Prioritizing vulnerable populations. Retrieved from https://www.thenationshealth.org/content/51/2/1.1

Meskell, Z. (2020). Corruption and the COVID-19 vaccine: the looming problem of distribution. The Global Anticorruption Blog. Retrieved from https://globalanticorruptionblog.com/ 2020/10/26/corruption-and-the-covid-19-vaccine-the-loomi ng-problem-of-distribution/

Mietzner M (2020) Populist anti-scientism, religious polarisation, and institutionalised corruption: how Indonesia's democratic decline shaped its COVID-19 response. Journal of Current Southeast Asian Affairs 39(2):227-249. https://doi.org/10.1177/ 1868103420935561

Mondal, A., \& Roy, S. K. (2021a). Application of Choquet integral in interval type-2 Pythagorean fuzzy sustainable supply chain management under risk. International Journal of Intelligent Systems.https://doi.org/10.1002/int.22623

Mondal A, Roy SK (2021b) Multi-objective sustainable openedand closed-loop supply chain under mixed uncertainty during COVID-19 pandemic situation. Comput Ind Eng 159:107453. https://doi.org/10.1016/j.cie.2021.107453

Naher N, Hoque R, Hassan MS, Balabanova D, Adams AM, Ahmed SM (2020) The influence of corruption and governance in the delivery of frontline health care services in the public sector: a scoping review of current and future prospects in low and middle-income countries of south and south-east Asia. BMC Public Health 20:1-16. https://doi.org/10.1186/s12889-020-08975-0

Nicola M, Alsafi Z, Sohrabi C, Kerwan A, Al-Jabir A, Iosifidis C, Agha R (2020) The socio-economic implications of the coronavirus pandemic (COVID-19): a review. International Journal of Surgery (london, England) 78:185. https://doi.org/10.1016/j. ijsu.2020.04.018

Nicole, H. (2021). Why COVID-19 vaccine distribution methods fall short and 3 ways to improve them. Retrieved from https:// www.newswise.com/coronavirus/why-covid-19-vaccine-distr ibution-methods-fall-short-and-3-ways-to-improve-them/?artic le_id $=746630$

O'Reilly KM, Auzenbergs M, Jafari Y, Liu Y, Flasche S, Lowe R (2020) Effective transmission across the globe: the role of climate in COVID-19 mitigation strategies. The Lancet Planetary Health 4(5):e172. https://doi.org/10.1016/S2542-5196(20) 30106-6

Olamide, E. G., \& Maredza, A. (2021). Pre-COVID-19 evaluation of external debt, corruption and economic growth in South Africa. Review of Economics and Political Science.https://doi.org/10. 1108/REPS-03-2021-0019

Ortega F, Orsini M (2020) Governing COVID-19 without government in Brazil: Ignorance, neoliberal authoritarianism, and the collapse of public health leadership. Glob Public Health 15(9):1257-1277. https://doi.org/10.1080/17441692.2020.1795223

Peters DH, Garg A, Bloom G, Walker DG, Brieger WR, Hafizur Rahman M (2008) Poverty and access to health care in developing countries. Ann N Y Acad Sci 1136(1):161-171. https://doi.org/ 10.1196/annals.1425.011

Priborkin, E. (2021). How equitable is the distribution of COVID19 vaccines. Retrieved from https://www.american.edu/sis/news/ 20210309-how-equitable-is-the-distribution-of-covid-19-vacci nes.cfm

Rahman, K. (2021). Mitigating corruption risks in COVID-19 vaccine rollout. Retrieved from https://www.u4.no/publications/mitig ating-corruption-risks-in-covid-19-vaccine-rollout

Rose-Ackerman, S. (2021). Corruption and COVID-19. EUNOMÍA. Revista en Cultura de la Legalidad(20), 16-36. https://doi.org/ 10.20318/eunomia.2021.6061

Ryan SJ, Carlson CJ, Mordecai EA, Johnson LR (2019) Global expansion and redistribution of Aedes-borne virus transmission risk 
with climate change. PLoS Negl Trop Dis 13(3):e0007213. https:// doi.org/10.1371/journal.pntd.0007213

SEKO. (2021). The Logistics Challenges of COVID-19 Vaccination distribution. Retrieved from https://www.supplychain247.com/ article/the_logistics_challenges_of_covid_19_vaccination_distr ibution

Steingrüber, S., Kirya, M., Jackson, D., \& Mullard, S. (2020). Corruption in the time of COVID-19: a double-threat for low income countries. U4 Anticorruption Resource Center. U4 Brief, 6. Retrieved from https://www.u4.no/publications/corruption-in-thetime-of-covid-19-a-double-threat-for-low-income-countries.pdf

Teremetskyi V, Duliba Y, Kroitor V, Korchak N, Makarenko O (2020) Corruption and strengthening anti-corruption efforts in healthcare during the pandemic of Covid-19. Med Leg J 89(1):25-28. https:// doi.org/10.1177/0025817220971925

Transparency-International. (2021). COVID-19 Vaccine Transparency. Retrieved from https://www.transparency.org/en/news/covid-19vaccine-transparency\#

UNODC. (2021a). Corruption and COVID-19. Retrieved from https:// www.unodc.org/unodc/en/corruption/covid19.html

UNODC. (2021b). UNODC Addresses Corruption Risks Related to COVID-19 Vaccines. Retrieved from https://www.unodc.org/ unodc/en/frontpage/2020/December/unodc-addresses-corruptionrisks-related-to-covid-19-vaccines.html

Usman, M., Husnain, M., Riaz, A., Riaz, A., \& Ali, Y. (2021). Climate change during the COVID-19 outbreak: scoping future perspectives. Environmental Science and Pollution Research, 1-12.https:// doi.org/10.1007/s11356-021-14088-x

Vrushi, J., \& Kukutschka, R. (2021). Why fighting corruption matters in times of Covid-19. Corruption perceptions index 2020: Research analysis. Retrieved from https://www.transparency.org/ en/news/cpi-2020-research-analysis-why-fighting-corruptionmatters-in-times-of-covid-19
Wang Z, Zhang B, Wang B (2018) The moderating role of corruption between economic growth and $\mathrm{CO} 2$ emissions: evidence from BRICS economies. Energy 148:506-513. https://doi.org/10. 1016/j.energy.2018.01.167

Welsch H (2004) Corruption, growth, and the environment: a crosscountry analysis. Environ Dev Econ 9(5):663-693. https://doi.org/ $10.1017 / \mathrm{S} 1355770 \mathrm{X} 04001500$

Wendy R, S. (2021). During the coronavirus epidemic, we will be separated. We still have to stick together. Retrieved from https://www. google.com/amp/s/amp.usatoday.com/amp/5025089002

Woodby, B., Arnold, M. M., \& Valacchi, G. (2020). SARS-CoV-2 infection, COVID-19 pathogenesis, and exposure to air pollution: What is the connection? Annals of the new York Academy of Sciences.https://doi.org/10.1111/nyas.14512

Woodside AG (2020) Interventions as experiments: Connecting the dots in forecasting and overcoming pandemics, global warming, corruption, civil rights violations, misogyny, income inequality, and guns. J Bus Res 117:212-218. https://doi.org/10.1016/j.jbusr es.2020.05.027

Yamen, A. E. (2020). Tax evasion, corruption and COVID-19 health risk exposure: a cross country analysis. Journal of Financial Crime.https://doi.org/10.1108/JFC-10-2020-0220

Zhang Y-J, Jin Y-L, Chevallier J, Shen B (2016) The effect of corruption on carbon dioxide emissions in APEC countries: a panel quantile regression analysis. Technol Forecast Soc Chang 112:220-227. https://doi.org/10.1016/j.techfore.2016.05.027

Publisher's Note Springer Nature remains neutral with regard to jurisdictional claims in published maps and institutional affiliations. 